\title{
THE PROTESTANT CHURCH AS INSTITUTION OF INTERPRETATION AND ORGANIZATION OF ACTION IN MODERN SOCIETY
}

\author{
Michael Haspel \\ Systematic Theology \\ Stellenbosch University ${ }^{1}$
}

\begin{abstract}
Starting from an analysis of Francis Schuessler Fiorenza's argument for a political theology based on the notion of the church as a community of interpretation, this essay argues that, from a Protestant perspective, the church in modern societies should be seen, both theologically and sociologically, as institution or organization, rather than as community $(1,2)$. The church is faced not only with a diversity of interpretations of tradition, but in fact with a legitimate diversity of interpretive aims, and therefore modes (3). The essay suggests that the specific mode of interpretation of the ethical tradition aiming at participation in the public discourse should be understood as contextualization (4), and the church properly understood as institution or organization in the life-world in modern societies (5) can not only contribute meaningfully to ethical public discourse but also facilitate public moral action (6).
\end{abstract}

Francis Schuessler Fiorenza suggested in his somewhat famous essay "The Church as a Community of Interpretation", that the church could provide the locus for ethical discourse in modern society, which is missing in the concept of Juergen Habermas' discourse ethics. He argues that the church could also provide substantial content to the normative public discourse by developing a political theology, which through a wide reflective equilibrium can combine the hermeneutical reconstruction of the Christian tradition with the rational standards of discourse ethics. ${ }^{2}$

I have argued elsewhere, that the suggested concept of political theology based on a wide reflective equilibrium between hermeneutical reconstruction and discourse ethics is neither very clear nor solving the problem of how the particular ethical tradition of religious

1. I am deeply indebted to the Faculty of Theology of Stellenbosch University, which invited me as a visiting scholar in October and November 2001. This provided the opportunity for the writing of this essay. I am also grateful to the universities of Stellenbosch and Marburg for providing support for this visit through their mutual faculty exchange program. I profited a lot from commentaries and criticism I received when I presented a previous version to the Faculty of Theology in Stellenbosch and also from the inspiring atmosphere, collegial conversations and warm hospitality I had the privilege to experience in Stellenbosch. I am also grateful to Stefan Grotefeld, Matthias Koenig and Thomas Miertschischk who gave critical yet constructive commentaries on an earlier version of this paper. I am deeply indebted to Eve Mullen who once more skillfully helped with the English editing of the text.

2. The essay appeared in printing first in German in the collection of essays, which was dedicated to Juergen Habermas' 60th birthday in 1989 (Fiorenza, Francis Schuessler: Die Kirche als Interpretationsgemeinschaft. Politische Theologie zwischen Diskursethik und hermeneutischer Rekonstruktion, in: Arens, Edmund (ed.): Habermas und die Theologie, Duesseldorf, $2^{\text {nd }}$ ed. 1989, pp. 115-144), before the English (original) version appeared in 1992 (Fiorenza, Francis Schuessler: The Church as a Community of Interpretation: Political Theology between Discourse Ethics and Hermeneutical Reconstruction, in: Browning, Don S; Fiorenza, Francis Schuessler (eds.): Habermas, Modernity, and Public Theology (New York: Crossroad), 1992, pp. 6691. For references and quotations I use the English text. 
communities can meet the supposedly rational standards of public discourse. In addition, my analysis of the notion of "community" produced the result, that in the context of modern society it would be more adequate to conceive the church as institution respectively organization rather than as community. ${ }^{3}$

In this article, I want to suggest that, from a theological as well as a sociological perspective, the church has to be perceived in modern society as an institution or organization rather than as community. Starting with objections stemming from ecclesiology - at least in a Protestant perspective - against the understanding of the church as a "community" of interpretation (1), I will further argue that interpretation in the modern society is dependent on institutionalization, rather than on community (2). Yet, we are not only confronted with the problem of diversity of interpretations but with a diversity of views on interpretation. This means, that there are different aims of interpretation, which might necessitate different modes of interpretation. This has to be clarified not only in order to elucidate the concept of interpretation but also of the church (3). Following from this, I suggest that one should conceptualize such an interpretation of ethical tradition aiming at participation in the public discourse as "contextualization" (4). Then it can be clarified that the church should be understood as an institution or organization in the life-world (5) which can contribute not only to the ethical discourse in society but also to facilitate moral action (6).

\section{Ecclesiological Aspects of the Church as a Community of Interpretation}

Given the definition of the Church as sanctorum communio in the Apostolic Confession and the repetition of this formulation in the major confessions of the reformation, ${ }^{4}$ it seems nearly natural to speak theologically of the church as community. But the lexem "community" can denote (and connote) quite some different semantems, including the ecumenical (kontroverstheologische) dimension. Thus it is necessary to explore further, what implications the usage of "community" by Francis Schuessler Fiorenza has.

With the model of "The Church as a Community of Interpretation" Francis Schuessler Fiorenza, by adapting the concept of reception aesthetics, ${ }^{5}$ seems to intend to establish something we could call upside-down Catholicism, an understanding of the Catholic Church, which is turned from the head to the feet, as Marx described his handling of Hegel. This implies two propositions: Firstly, Francis Schuessler Fiorenza is providing a specific catholic concept of the church (and consequently of interpretation), and by the same token he is transforming it decisively. Or, to put this in other words, though he is radically disagreeing with the conventional catholic ecclesiology, his suggested innovation is still a distinctly catholic one.

His concept is based on the presupposition that the church is the highest, best authority to decide on the validity of Christian teaching. The criterion for validity is actually approval by the church, which draws from the authorities of Scriptures and unwritten traditions,

3. Cf. Haspel, Michael: Hermeneutical Reconstruction and Discourse Ethics. A Critical Assessment of Francis Schuessler Fiorenza's Concept of "The Church as a Community of Interpretation”, Scriptura 82, 2003, pp. 4962.

4. Cf. for example Confessio Augustana VII. For the history of the term and concept cf. Haerle, Wilfried: Art. "Kirche VII: Dogmatisch", in: TRE 18, pp. 277-317.

5. Cf. Fiorenza, Francis Schuessler: Foundational Theology. Jesus and the Church (Crossroad: New York) 1986, pp. 301-311; idem: "The Crisis of Scriptural Authority. Interpretation and Reception", in: Interpretation 44, 1990, pp. 363-368; Smit, Dirkie J: Biblical Hermeneutics in the 20th Century, in: Maimela, S; Koenig, A (eds.): Initiation into Theology. The Rich Variety of Theology and Hermeneutics (Pretoria: Van Schaik) 1998, pp. 297-317. 
based on what Troeltsch called a "culture of authority." 6 Thus it seems no problem for Fiorenza to accept the church as the authority, which, based on tradition and Scripture, gives the binding interpretation of the Gospel. This would be much more difficult to accept for orthodox Protestants, who see the Scripture as norma normans, the highest authority binding the church and any interpretations, even the fundamental ones such as confessions as norma normata (though this understanding might be challenged even from a Protestant perspective). By ascribing this competence to the community of the readers or listeners, he transfers the authority from the church hierarchy to the constituency, the community of believers, which is not a small assault on the official catholic understanding of the church. ${ }^{7}$ Protestants should not have a problem with the latter one, but orthodox Protestants, at least Lutherans and Reformed people alike, will have a problem with the authority ascribed to the church and not to Scriptures.

It also seems that the question of the relationship between "community" and "institution" is not a trembling one in a Catholic perspective, given the understanding that the church is a (necessary) means of salvation and the community of believers is only possible in a (hierarchically) institutionalized and organized way. For Protestants this is again much more difficult to conceive, given the traditional distinction between the organized church (ecclesia visibilis) and the community of the true believers, the truly elected (ecclesia invisibilis or better abscondita). ${ }^{8}$

The whole endeavour can be interpreted as an attempt to modernize the concept of the church (and consequently the church itself). By transferring the authority from the church hierarchy to the inter-subjectively established consensus within the community/institution, this re-conceptualization reacts to the requirements of modern communication based on communicative reason. It is also a transformation from the medieval principle of "authority" to the modern principle of "autonomy." Against this background his concept of "hermeneutical reconstruction" gains plausibility. It is the attempt to combine reception aesthetics with the Rawlsian concept of the wide reflective equilibrium and catholic institutionalism. One could say the authoritative community of recipients establishes equilibrium between the hermeneutical reconstruction of written tradition (Scripture) and non-written traditions (retroductive warrants) in the light of relevant background theories. This is not a bad idea, yet not exactly what discourse ethics is meant to be, or something to which the ordinary non-catholic would necessarily be ready to subscribe.

But this attempt of modernization does not fully take into account what Troeltsch calls religious individualism, which includes that religiosity is not exclusively located within the church. ${ }^{10}$ The religious tradition itself, thus, cannot be identified totally with the church. Religion, even a specific tradition, is under modern conditions not co-extensive with the established church (though one might want to argue that exactly this communicative

6. Cf. Denzinger, Heinrich: Kompendium der Glaubensbekenntnisse und kirchlichen Lehrentscheidungen, verbessert, erweitert, ins Dt. uebertragen und unter Mitarbeit v. H Hoping hg. v. P Huenermann, Freiburg u.a., 37. Aufl. 1991, 1501 (Denz. 783); Troeltsch, Ernst: Die Bedeutung des Protestantismus fuer die Entstehung der modernen Welt, (Historische Bibliothek, Bd. 24) München/Berlin 1911, p. 10.

7. It would be interesting to compare this concept with Elisabeth Schuessler Fiorenza's concept of the WomenChurch. Cf. Fiorenza, Elisabeth Schuessler: Bread Not Stone. The Challenge of Feminist Biblical Interpretation (Beacon Press: Boston) 1984.

8. Cf. Haerle: Kirche, pp. 286-289.

9. Cf. Troeltsch, Ernst: Die Bedeutung des Protestantismus fuer die Entstehung der modernen Welt, (Historische Bibliothek, Bd. 24) Muenchen/Berlin 1911, p. 12.

10. The prevalence of the community over the individual is obvious in Fiorenza: The Crisis of Scriptural Authority, p. 364 somehow counteracting his own claim of religious individualization in the other essay. 
network among one tradition, as loosely tied as it might be, constitutes the church as institutionalized discourse). ${ }^{11}$

The catholic conception does not differentiate the different types in which and for what one interprets the Bible. It might be something quite different to read, respectively to interpret, a narration of the Bible for the sake of existential-self understanding, the establishment and sustenance of faith, or to interpret entire Scripture in order to make true statements about the objective world, or finally to interpret the normative potential of Scripture for the sake of inter-subjectively establishing social order. This lack of differentiation in Francis Schuessler Fiorenza's concept can be traced back to traditional catholic teaching where the teachings of faith (fides; credenda) and the teachings of ethics (mores; agenda) are inseparable and authorized by the church. Not only does Habermas' discourse theory suggest that the validity claims in different realms have to be distinguished from each other, but I would also claim that for Protestant theology the use - and therefore interpretation - of Scripture follows different lines when it comes to the awakening of faith or the norms of action (which might be easier to accept for Lutherans than for Reformed people and for neo-Protestants easier than for orthodox ones). ${ }^{12}$

The church herself has to be interpreted as interpretation. She is creatura verbi, founded on the word of God, which is Jesus as Christ. Providing for the interpretation of the word of God, she herself has to be an expression of that word, being an interpretation and consisting of processes of interpretations. Correlating these aspects of content and form is the old task of ecclesiology, addressed by the aforementioned distinction between ecclesia visibilis and ecclesia abscondita. Struggling with this problem his whole lifetime, Dietrich Bonhoeffer insisted on the importance of the ecclesia visibilis, for the church being church at all. ${ }^{13} \mathrm{He}$ also insisted on the necessity of an analogical relationship of the two aspects of the church. ${ }^{14}$ How that was attempted and partially achieved in changing societal and cultural contexts is the subject of Ernst Troeltsch's account of "Die Soziallehren der Christlichen Kirchen und Gruppen." How that can be conceptualized in the current societal formation according to the analysis of Habermas is the topic of the following sections.

11. Cf. for the analysis of Troeltsch: Fechtner, Kristian: Religieser Individualismus. Und Kirche: Praktischekklesiologische Perspektiven im Anschluß an Ernst Troeltsch, in: idem; Haspel, Michael (eds.): Religion in der Lebenswelt der Moderne, Stuttgart / Berlin / Koeln 1998, pp. 208-226. It is obvious that Habermas takes over this undifferentiated view of "church" in his reactions towards the writings of catholic theologians. Cf. Habermas, Juergen: "Israel und Athen oder: Wem gehoert die anamnetische Vernunft? Zur Einheit in der multikulturellen Vielfalt”, in: Metz, Johann Baptist et al.: Diagnosen zur Zeit, Duesseldorf 1994, pp. 51-64.

12. I developed this argument in depth in: Cf. Haspel, Michael: Konzept einer Theorie protestantischer Sozialethik in der modernen Gesellschaft, in: Konstitution und Applikation protestantischer Sozialethik in der modernen Gesellschaft am Beispiel der Friedensethik in Auseinandersetzung mit dem Krieg der NATO gegen die Bundesrepublik Jugoslawien, habil. theol. Marburg 2001, pp. 7-87, pp. 43-78. Cf. idem: "Homophober Biblizismus. Vom sola scriptura zum tota scriptura bei der ethischen Urteilsbildung in bezug auf sexuelle Orientierung und gleichgeschlechtliche Lebensgemeinschaften", in: Keil, Siegfried; idem (eds.): Gleichgeschlechtliche Lebensgemeinschaften in sozialethischer Perspektive. Beitraege zur rechtlichen Regelung pluraler Lebensformen, Neukirchen-Vluyn 2000, pp. 123-149.

13. Bonhoeffer, Dietrich: Sanctorum Communio. Eine dogmatische Untersuchung zur Soziologie der Kirche, (DBW 1), Muenchen 1986 (1930). Though it has to be admitted, that he, at least in this early writing, insists on the church being a "community."

14. This aspect grew more important confronted with the penetration of National Socialist ideology into the church in Germany in the 1930s. For the development of his ecclesiology cf. Lange, Ernst: Kirche für andere. Dietrich Bonhoeffers Beitrag zur Frage einer verantwortbaren Gestalt der Kirche in der Gegenwart, in: idem: Kirche für die Welt. Aufsaetze zur Theorie kirchlichen Handelns, München/Gelnhausen 1981, pp. 19-62. 


\section{The Necessity of Institutionalized Interpretation}

Starting from his proposition that modern Protestantism finds its adequate expression in "religious individualism", which he also takes to be the most fitting form of religiosity in modernity Troeltsch concludes that the days of the pure type of the established church are to be over soon. ${ }^{15}$ The traditional form of the church in modernity seems to be broken by increasing individualism, which others view not only as the end of a certain gestalt of the church, but as the enemy that must be encountered and destroyed.

Kristian Fechtner's advice for dealing with the problem is not only elegant but also theologically and sociologically convincing. He agrees with Troeltsch that individuality is not a fearful penetration of the church from outside. But neo-Protestantism (Neuprotestantismus) itself has in a process of co-evolution with modernity given up the "culture of authority", which had in orthodox Protestantism merely replaced the authority of church hierarchy by the authority of Scripture. ${ }^{16}$ Neo-Protestantism is intertwined with the insight in the fundamentality of the individual's religious belief, thus embracing the principle of (not only religious) autonomy of the individual and by the same token the individualization and pluralization of modern society. If these features are not external and alien to Protestantism, but are actually partly triggered by it, they also have to be seen as intrinsic to Protestantism providing the measures to which the modes of Protestantism's institutionalizations have to comply.

For the transmission and interpretation of religious tradition(s) this means that the actualization, which is always more than a mere reconstruction, ${ }^{17}$ gains its validity not on an institutional level beyond the individuals, but the very individual insight in the meaning, and affirmation of the significance of the meaning cannot be evaded. Yet, in turn, interpretation, even done in solitude, is dependent on the discourse of interpretation in the context of which individual interpretation takes place. But discourse by the very meaning of the word is institutionalized communication. ${ }^{18}$ And individual as well as communal interpretations are dependent on it. Actually one could say, and this is the quintessential insight, which we owe to Kristian Fechtner, that individual religiosity by individual interpretation or reading is only possible in the context of institutions, and even more pointedly, the constitution of individuality presupposes the horizon of institution. ${ }^{19}$ One could restate this argument and suggest that the mere complexity of modernity makes it necessary that the individual participates in the relieving function of institution, even when it comes to its very individual religiosity. Though, the responsibility for the individual appropriation cannot be transferred to any external authority.

Fechtner's argument, developed in the perspective of Practical Theology, dealing with the relation of "religious individualism" and the church, makes perfect sense also when transferred (and partially transposed) to systematic theology, especially (social) ethics. As a moral and intelligible being, and as a Christian believer, the individual, indeed, cannot be

15. Cf. Troeltsch, Ernst: Die Soziallehren der christlichen Kirchen und Gruppen, GS I, Tuebingen 1912, p. 981. In my interpretation of Troeltsch I follow the analysis of Fechtner: Religioeser Individualismus, see p. 221.

16. Cf. Troeltsch: Die Bedeutung des Protestantismus, pp. 24-31.

17. Therefore it is correct to object to a hermeneutical theology and to claim instead a concept for theological hermeneutics. Cf. Nethoefel, Wolfgang: Theologische Hermeneutik. Vom Mythos zu den Medien, (Neukirchener Beitraege zur Systematischen Theologie, Bd. 9), Neukirchen-Vluyn 1992.

18. In this sense the New Testament metaphors for the relationship among believers and their relationship with the risen Christ -which are often interpreted as denoting community- are applicable to the concept of institution. Cf. Kaesemann, Ernst: Das theologische Problem des Motivs vom Leibe Christi, in: idem: Paulinische Perspektiven, Tübingen, 3rd ed. 1993, pp. 178-210.

19. Cf. Fechtner: Religioeser Individualismus, pp. 223f. 
replaced by any other authority when it comes to ethical reflection and moral action. However, the complexity of modern society makes it impossible for any individual to take responsible account of all circumstances regarding any ethical question. Moreover, ethical reflection, including the justification of normative claims, can only take place in institutionalized discourse, respectively as institution. With reference to Habermas one could add that the justification of normative claims according to the discourse principle "D" requires that consensus is found in practical discourse of all potentially affected, which is in itself the institutionalization of inter-subjectivity, while the individual as an individual is not replaceable in this process. The conclusion can be drawn that interpretation in a theological understanding presupposes institution. The structures of interpretation however remain subject to further clarification.

\section{The Diversity of Interpretation}

The topic of this section is not the diversity or plurality of interpretations that always occur in processes of interpretation due to the different pre-understandings, interests and perspectives of interpreters. Rather, I want to highlight here that the activity of interpretation itself has very different aims. This is also true for religious interpretations, more specific the interpretation of Scripture in Christianity, respectively Protestantism.

Interpreting Scripture as source of existential self-interpretation, which can exclusively and sufficiently tell us about the content and character of redeeming faith, Jesus Christ, the word of God, or seeking ethical guidelines for complex social issues in modern society, are two totally different endeavors. I have argued elsewher ${ }^{20}$ that the sola scriptura-principle of the Protestant reformations in the $16^{\text {th }}$ century is only applicable (and that it is necessary to apply) to the soteriological interpretation of Scripture. ${ }^{21}$ The Scriptures are primarily a book of faith and they are not a legal code (though, as we know, it includes different legal corpora). It is from my perspective one of the most fundamental errors, to which a lot of the confusion and opacity regarding the understanding of interpretation of Scripture is attributable, not to distinguish these two categories. It is a very feature of neo-Protestantism, understood as that gestalt of Protestantism which is co-developing with modernity, not to base ethical claims (as well as propositions about the objective world) directly on the authority of Scripture (or church hierarchy) but on the institutionalized discourse of autonomous individuals. This is in my view consistent with the insight of the important essay of James Gustafson:

Scripture alone is never the final court of appeal for Christian ethics. Its understanding of God and his purposes, of man's condition and needs, of precepts, events, human relationships, however do provide the basic orientation toward particular judgments. Within that orientation many complex procedures and appeals are exercised, and there is room for a great deal of argumentation. ${ }^{22}$

Thus, this distinction, to make it crystal clear, does not deny the importance of Scripture in general, nor does this imply that Scripture is of no use at all in the field of ethics. But ethical claims - not solely public ones but also the ones related to the task of explication,

20. Haspel: Konzept einer Theorie protestantischer Sozialethik in der modernen Gesellschaft, pp. 43-78. Cf. idem: Homophober Biblizismus, pp. 123-149.

21. Cf. Ebeling, Gerhard: "Sola scriptura" und das Problem der Tradition, in: Käsemann, Ernst (ed.): Das Neue Testament als Kanon, Goettingen 1970, pp. 282-335.

22. Gustafson, James: The Place of Scripture in Christian Ethics: A Methodological Study, in: Interpretation 24, 1970, pp. 430-455, p. 455. 
what ethically should be desirable for those who participate in the institutionalized ethical discourse of Protestantism - cannot be justified by the mere authority of Scripture.

It remains, of course, true that faith can ultimately not do without the justifying and liberating meaning which Biblical stories and accounts may provide in our reading, listening to and experiencing them. Therefore, although Scripture cannot be seen as auctoritas normativa when it comes to the foundation of norms, it can most certainly function in different ways related to different levels or elements of social ethics, ${ }^{23}$ ethics consisting of more than only justifying norms. For example, biblical narrations can provide motivation, they can stimulate new insights for the application of norms, they may support the development of virtues, the reading and analysis of the Bible may provide substantial insights about fundamental values, and last but not least this may illuminate the nature of human being.

In addition, different biblical texts and traditions will have different status in regard to ethics. Some texts may be constitutive, others do contain principles, while others are paradigmatic. Some will have value as examples, while others are only important for the singular situation they were written for. ${ }^{24}$

If we relate the functions that the interpretation of biblical texts can serve to the different status the texts can have, we get a complex matrix of relations: a complexity, which can provide clarification by differentiation. By helping people involved in interpretation to actually understand what they are doing, it might facilitate responsibility and engender more adequate interpretations. ${ }^{25}$

\section{The Discourse of Interpretation as Contextualization}

We have seen that biblical interpretation is not a homogenous activity done with the same aims and the same tools in every single case. In fact, preaching from a pulpit in a Sunday service to a congregation of believers or using perhaps the same text in a discourse about public policy are quite different actions. If we have a look at Habermas' discourse theory, this might help us to differentiate further the kinds of claims, which are implicitly made by certain modes of interpretation.

He distinguishes three world-relations to which different validity claims correspond: the validity claim of truth to the objective world, the validity claim for rightness within the social world and the validity claim for truthfulness (authenticity) within the subjective world. All use different modes of rationality: cognitive-instrumental, moral-practical, and aesthetic-practical. ${ }^{26}$ In terms of discourses of interpretation this would help us to differentiate existential self-interpretation in, let us say, preaching and counseling making

23. Cf. in my Konzept einer Theorie protestantischer Sozialethik in der modernen Gesellschaft, I have identified nine different elements of a theory of social ethics (p. 11-25), which are restated in the following article: Gesellschaftliche Modernisierung als Bezugsproblem philosophischer und theologischer (Sozial-) Ethik, in: Quellen Oeffentlicher Moral - zum Streit um Religion und Ethik. Jahresbericht der Societas Ethica 2001, Arhus 2002, pp. 117-128.

24. I have developed and further explained these five different ways, in which biblical texts can be used in ethics in: Konzept einer Theorie protestantischer Sozialethik in der modernen Gesellschaft, pp. 74-78. Cf. also Homophober Biblizismus.

25. This might be consonant with Dirkie Smit's quest to interpret Scripture responsibly and at the same time not giving up the powerful impact it can unleash. Cf. inter alia: "The Ethics of Interpretation - and South Africa", in: Scriptura 33, 1990, pp. 29-43; "Reading the Bible and the "(Unofficial) Interpretative Culture", in: Neotestamentica 28, 1994, pp. 309-321.

26. Cf. Habermas, Juergen: Theory of Communicative Action II. "Lifeworld and System: A Critique of Functionalist Reason" (Boston: Beacon Press, 1987), especially the intermediate reflections, pp. 113-197. See also Fiorenza: The Church as a Community of Interpretation, pp. $69 \mathrm{f}$. 
mainly validity claims of truthfulness from systematic theological reasoning that tries to provide true propositions, and the field of ethics, where validity claims of rightness are made. They might be processes according to different kinds of rationality and different modes of justification. ${ }^{27}$

They are, however, all institutionalized discourses in the life-world of modernity. Thus the processes of rationalization, which affect the life-world, are the framework in which the discourses of interpretation take place. The very signature of modernity is also inherent in the church as institution of interpretation. Individualization and pluralization are not alien structures existing outside the church, but are part and parcel of modern Protestantism. Thus the distinction between an internal process of interpretation modeled as "hermeneutic reconstruction" and a public mode of justification as "discourse ethics" does not correspond with the very structure of the church as institutionalized discourse. ${ }^{28}$ The dividing line thus is to be found not in the mode of discourse, but in the purpose and particular substance. The claim that the particular substance represented by the Bible and the institutionalized tradition of its interpretation could prove helpful in interpreting the individual's different world-relations is obviously the kind of claim, which could not be defended as a truth claim, but indeed as a claim of truthfulness. It is precisely from this (kind of) starting point that people enter a specific discourse. As long as this is a particular discourse and they remain aware of this, the purpose is clearly not a public one, but limited to that discourse, where people share this assumption. This again implies that the fundamental ability to make this distinction is one of the basic requirements inherent in making any rationally justified validity claim in modernity. At the same time, the forms of justification within this (or any) particular discourse are also not arbitrary. The standards of rationality, accepted as givens in the life-world of modernity, cannot be evaded randomly. As I tried to show, this is not something external to the discourse, but particular traditions are themselves affected by the fundamental structure of modernity. Thus, interpretations on which validity claims are based will only be acceptable in the discourses of particular traditions if they also can be sustained with adequate rational arguments. The justifications for certain claims will only work as long as the participants in this discourse accept them as based on valid arguments.

Yet since these practices of interpretation are all inherently rational discourses, they are in principle compatible with public discourse. It might be that certain arguments would not be acceptable for the broader public, but others would. The mode of discourse is the same, though empirically it might be the case that certain arguments would not be accepted and addressing the normative sphere - that the consensus which is reached in public discourse about what should be regarded as desirable for society at large or should even be enforced by law, may differ from what participants of a specific discourse find desirable. According to Habermas, we will only find out in practical discourse. By doing so, Protestantism will be able to re-interpret its own tradition discursively in a way which meets the given contexts of individuals, culture, and society. By this contextualization the good news of the

27. This may also respond to von Soosten's critique (Soosten, Joachim von: "Kommunikation und Religion. Obsoleszenz und Affirmation von Religion" in der Theorie von Juergen Habermas, in: Tyrell, Hartmann u.a. (eds.): Religion als Kommunikation, (Religion in der Gesellschaft, Bd. 4), Wuerzburg 1998, pp. 273-300, here pp. 290-294), that Habermas' concept of discourse does not allow for taking ritual and textual communication seriously, since in this framework ritual and textual communication may function in different ways, yet ritual communication may not necessarily be seen as a mode of justification for claims of truth or rightness, even though it may contribute to the building of personality, trust, reliable social relations et cetera.

28. Cf. Fiorenza: The Church as a Community of Interpretation and my critique Haspel, Michael: Hermeneutical Reconstruction and Discourse Ethics. A Critical Assessment of Francis Schuessler Fiorenza's Concept of "The Church as a Community of Interpretation", in footnote 3. 
Gospel can be understood and the ethical claims might find acceptance in the horizon of the modern lifeworld.

\section{The Church as Institution and Organization in the Life-world}

The church, in theological as well as in social scientific perspective, is an institutionalized form of communicative action, and thus an institution in the life-world upholding communicative reason against different forms of penetrating systemic imperatives (such as economic or bureaucratic rationales). The theological task of the church, the preaching of the Gospel, is in itself an eminent act of guaranteeing the reproduction of the life-world through the different structural components. If the discourses are structured as described above, they also are potentially able to influence those (normative) institutions, which are supposed to transpose the normative consensus of the life-world into the steering process of the system. ${ }^{29}$

Moreover, the churches as organizations provide necessary human and material resources for the genesis and sustenance of discourses. And they do so for internal discourses, but they also provide in many cases the infrastructure for and function as the organizational backbone of public discourse, as Black churches for example did in the Civil Rights Movement in the United States of America, as well as the Protestant Churches in the process of transformation in East Germany,${ }^{30}$ and last but not least many South African churches in the struggle against apartheid and beyond.

In conclusion, it can be clarified that the church is as an institution part of the lifeworld, perhaps participating in the institutions aimed at influencing the system. As organizations, churches function as backbones for internal discourses and provide loci for public discourse. $^{31}$

\section{The Churches as Organizations of Moral Action}

I argued that it is necessary to distinguish between faith and action when it comes to the use of Scripture, especially when the sola scriptura-principle is applied. This does not imply, however, that faith and action should be or, to make it still clearer, can be separated at all. Though the use of Scripture is indeed different with regard to these two aspects of Christian life, and in general the way of sustaining validity claims with regard to these two spheres has to be viewed differently, they are inseparably connected. The fundamental insight of the reformation that good deeds (action) cannot provide justification of the godless sinner is cofounded with the insight that the justification of the godless by the mere grace of God through faith alone will result in good (right) action of the justified. Luther and Zwingli

29. It has to be noted that the possibility of influencing the steering process of the system is not at all self-evident. It might be rather a normative prescription than an analytic description. Cf. also Haspel, Michael: Die evangelischen Kirchen in der DDR. Zur Institutionalisierung einer oeffentlichen Sphaere zwischen System und Lebenswelt, in: Rittersporn, Gábor; Rolf, Malte; Behrends, Jan (Hg.): Sphaeren von Oeffentlichkeit in Gesellschaften sowjetischen Typs, (Komparatistische Bibliothek, Bd. 11), Frankfurt u.a. 2003, pp. 239-253.

30. Cf. my cases studies in: Politischer Protestantismus.

31. Emphasizing the character of the church as institution, respectively organization, does not exclude that the church also comprises community and communities in various forms. To the contrary, different social forms of community are still very important for the church. Yet in a technical sense the structural principles of the church are those of institution, respectively organization. It is probably necessary to ask, given the current developments of information technology, whether the church/churches have also to transform from an "organization" into a "network". Cf. Nethoefel, Wolfgang: Ethik zwischen Medien und Maechten. Theologische Orientierung im Uebergang zur Dienstleistungs- und Informationsgesellschaft, NeukirchenVluyn 1999. 
used the concept of first and second justice to explain this correlation. The first justice is established by God; the second is the consequence and fruit of the first in the action of the justified in faith, traditionally referred to as sanctification. ${ }^{32}$

Thus, both the different discourses of interpretation of Scripture, and the understanding of the Protestant tradition as explicated here, point finally to action. And the churches as organizations provide by the same token the infrastructure for discursive interpretation and for individual and collective moral, social action. As my aforementioned case studies have shown, there is not only proof that churches are, at least in certain societal situations, likely to provide the backbone and framework for collective social action, but also that there is a deeper connection between the modes of interpretation and action. If the interpretation of Scripture, if the mode of discourse, take into account the actual cultural and societal codes and structures, the people participating in the Protestant discourse will not only be able to understand the meaning of interpretation and be motivated by it, but will be able to engage in resulting action adequate to the given cultural and societal situation. This would be possible due to the analysis of its structure made in the interpretative discourse. In this sense, contextualization is a necessity not only of interpretation but also for action.

If we face this challenge and take the task upon us, the justifying and liberating Gospel will find its gestalt in individual lives, cultural expressions and societal structures aimed at the goals of justice, equality, and freedom.

32. Cf. for example Luther, Martin: "Sermo de duplici iustitia (1518/19)", in: WA 2, Weimar 1884, pp. (143)145152. It is obvious that this is not an exhaustive explication of the concept of justification. It would not only be necessary to clarify how faith actually triggers (just) action, but also to explore more deeply how this individual process can be effective in complex modern society with its structural constraints on individual action. Notwithstanding, the relation between faith and action in the concept of justification has to be emphasized, though analytical distinctions of forensic and effective aspects of justification might help to understand this correlation of individual justification aiming on social justice. Cf. Haspel, Michael: Justification and Justice, in: Bloomquist, Karen; Greive, Wolfgang (eds.): The Doctrine of Justification: Its Reception and Meaning Today, (LWF Studies 02/2003), Geneva 2003, pp. 171-186; "Rechtfertigung, Versoehnung und Gerechtigkeit. Die Globalisierung als Herausforderung christlicher Soteriologie", in: ÖR 52, 2003, pp. 472-490. 